\title{
The absence of myelin basic protein promotes neuroinflammation and reduces amyloid $\beta$-protein accumulation in Tg-5xFAD mice
}

\author{
Ming-Hsuan Ou-Yang and William E Van Nostrand ${ }^{*}$
}

\begin{abstract}
Background: Abnormal accumulation of amyloid $\beta$-protein $(A \beta)$ in the brain plays an important role in the pathogenesis lof Alzheimer's disease (AD). $A \beta$ monomers assemble into oligomers and fibrils that promote neuronal dysfunction. This assembly pathway is influenced by naturally occurring brain molecules, the $A \beta$ chaperone proteins, which bind to $A \beta$ and modulate its aggregation. Myelin basic protein (MBP) was previously identified as a novel $A \beta$ chaperone protein and a potent inhibitor for $A \beta$ fibril assembly in vitro.

Methods: In this study, we determined whether the absence of MBP would influence A $\beta$ pathology in vivo by breeding MBP knockout mice $\left(\mathrm{MBP}^{--}\right)$with Tg-5xFAD mice, a model of AD-like parenchymal A $\beta$ pathology.

Results: Through biochemical and immunohistochemical experiments, we found that bigenic Tg-5xFAD/MBP ${ }^{-/-}$ mice had a significant decrease of insoluble $A \beta$ and parenchymal plaque deposition at an early age. The expression of transgene encoded human A PPP, the levels of $\mathrm{C}$-terminal fragments generated during A 3 production and the intracellular $A \beta$ were unaffected in the absence of MBP. Likewise, we did not find a significant difference in plasma $A \beta$ or cerebrospinal fluid $A \beta$, suggesting these clearance routes were unaltered in bigenic Tg-5xFAD/MBP ${ }^{-1-}$ mice. However, $\mathrm{MBP}^{-1-}$ mice and bigenic Tg-5xFAD/MBP ${ }^{-1-}$ mice exhibited elevated reactive astrocytes and activated microglia compared with Tg-5xFAD mice. The Aß degrading enzyme matrix metalloproteinase 9 (MMP-9), which is expressed by activated glial cells, was significantly increased in the $\mathrm{Tg}-5 \mathrm{xFAD} / \mathrm{MBP}^{-/-}$mice.
\end{abstract}

Conclusions: These findings indicate that the absence of MBP decreases A deposition in transgenic mice and that this consequence may result from increased glial activation and expression of MMP-9, an A $\beta$ degrading enzyme.

Keywords: Alzheimer's disease, Amyloid $\beta$-protein, Astrocyte, Chaperone molecules, Matrix metalloproteinases, Microglia, Myelin basic protein, Transgenic mice

\section{Background}

One of the pathological hallmarks of Alzheimer's disease $(\mathrm{AD})$ is the abnormal accumulation amyloid $\beta(\mathrm{A} \beta)$ aggregates in brain. $A \beta$ is a $38-43$ peptide produced from the sequential proteolysis of the amyloid precursor protein (A $\beta P P)$, a ubiquitously expressed type I membrane protein, by $\beta$ secretase [1] and $\gamma$ secretase $[2,3]$. The assembly of $A \beta$ into soluble oligomeric forms and fibrils is proposed to have a causative role in AD through various mechanisms [4]. Soluble oligomers have been shown to correlate with synaptic plasticity and memory deficit

\footnotetext{
* Correspondence: William.VanNostrand@stonybrook.edu

Departments of Neurosurgery \& Medicine, Stony Brook University, Stony
} Brook, NY 11794-8122, USA
[5,6]. Fibrillar $A \beta$ can promote oxidative stress and neuroinflammation, and is toxic to neuronal and vascular cells $[7,8]$.

The assembly of $A \beta$ is influenced by a number of naturally occurring brain factors, the 'A $\beta$ chaperone molecules' that bind and modulate the aggregation process of the peptide. One of the better known $A \beta$ chaperones is the apolipoprotein $\mathrm{E}(\mathrm{apoE})$ family. The apoE2 and apoE3 isoforms can suppress fibrillar $A \beta$ deposition, while apoE4 can promote fibril formation $[9,10]$. Studies using transgenic mice have demonstrated that by modulating the levels of these $A \beta$ binding partners, $A \beta$ deposition is delayed or enhanced [11]. Other examples of $A \beta$ chaperones include apolipoprotein J [12,13], members of heat shock 
proteins [14,15], $\alpha_{1}$-anti-chymotrypsin [16], transthyretin $[17,18]$, proteoglycans [19], and gangliosides [20,21].

Previously, we identified myelin basic protein (MBP) as a novel $A \beta$ chaperone that can potently inhibit its fibrillar assembly [22]. MBP is best known as a major structural protein in the central nervous system (CNS) myelin sheath. It is also suggested to have a role in intracellular signaling through interactions with membrane actin and tubulin [23]. MBPs are products of the Golli (genes of the oligodendrocyte lineage)-MBP gene complex [24]. Four major MBP isoforms are products of alternative splicing of the Golli-MBP gene complex $[25,26]$. The expression of the different MBP isoforms by oligodendrocytes is developmentally regulated. The predominant MBP isoform in mature human beings is 18.5 $\mathrm{kDa}[27,28]$. Although the $18.5 \mathrm{kDa} \mathrm{MBP}$ undergoes post-translational modifications to give rise to eight charge isomers, its ability to bind $A \beta$ appears to be solely sequence-dependent [22]. The strong binding of MBP to $A \beta 42$ was demonstrated to inhibit $A \beta$ fibril assembly in a substoichiometric molar ratio in vitro [29].

Interestingly, a number of studies have reported a loss of myelin and breakdown of MBP in AD patients and mouse models of AD pathology. This loss of myelin is associated with $\mathrm{AD}$ risk factors (for example, aging, apoE4, traumatic brain injury) [30-34] and an increase of $A \beta$ peptides [35]. Immunolabeling of brains for $A \beta$ showed that the most susceptible areas for its deposition are in gray matter, where little MBP is present. Conversely, areas of white matter that are abundantly supplied with MBP (for example, corpus callosum, striatum) exhibit very little $A \beta$ deposition. Furthermore, other studies showed there was no myelin staining inside amyloid plaques [36]. Taken together, these findings suggest an inverse correlation between the levels of MBP and $A \beta$. However, whether MBP can actually influence $\mathrm{A} \beta$ accumulation in vivo remains unknown.

Here, we directly tested whether MBP could modulate $A \beta$ in vivo by removing endogenous $M B P$ from a mouse model of $\mathrm{AD}$-like $\mathrm{A} \beta$ pathology. We took advantage of $\mathrm{MBP}^{-/-}$mice, known as shiverer mice, in which no functional MBP is produced due to a gene breakage from the middle of MBP exon II [37]. $\mathrm{MBP}^{-/-}$mice were crossed with human A $\beta P P$ transgenic mice $\mathrm{Tg}-5 \mathrm{xFAD}$, a model of parenchymal plaque amyloid pathology [38]. We show that in the absence of endogenous mouse MBP there was a significant reduction in cerebral $A \beta$ levels and the amount of deposited fibrillar amyloid. The reduction in $A \beta$ was not due to changes in expression or processing of human $\mathrm{A} \beta \mathrm{PP}$ or in clearance through cerebrospinal fluid (CSF) or plasma pathways. However, in bigenic Tg$5 \mathrm{xFAD} / \mathrm{MBP}^{-/-}$mice there was a significant elevation in activated astrocytes and microglia as well as in the levels of the A $\beta$-degrading enzyme MMP-9. Together, these findings indicate that in the absence of MBP there is a marked reduction in $A \beta$ pathology in $\mathrm{Tg}-5 \mathrm{xFAD}$ mice but that this decrease is likely to result from increased degradation via elevated neuroinflammatory glial cells and associated MMP-9.

\section{Methods}

\section{Animals}

All work with mice followed National Institutes of Health guidelines and was approved by the Stony Brook University Institutional Animal Care and Use Committee. Tg5xFAD mice were obtained from Jackson Laboratories. Tg-5xFAD mice coexpress human APP and human presenilin 1 with five familial AD mutations (APP K670N/ M671L + I716V + V717I and PS1 M146L + L286V) and develop early-onset $A \beta$ accumulation and fibrillar $A \beta$ plaques in the brain, starting at about two months of age [38]. Shiverer $\mathrm{MBP}^{-/-}$mice were also obtained from Jackson Laboratories. Shiverer $\mathrm{MBP}^{-/-}$mice produce no functional MBP, owing to a gene breakage from the middle of MBP exon II [37]. Hemizygous Tg-5xFAD mice were successively bred with $\mathrm{MBP}^{+/}$mice to obtain cohorts of wild-type mice, $\mathrm{Tg}-5 \mathrm{xFAD}$ mice, $\mathrm{MBP}^{-/-}$mice, and bigenic Tg-5xFAD/MBP ${ }^{-/-}$mice. 10 to 12 mice of each genotype were collected at two months of age.

\section{Tissue preparation}

Mice were overdosed with $2.5 \%$ Avertin followed by the collection of CSF, plasma and brain. CSF was obtained following a protocol adapted from [39]. Blood was collected through heart puncture with a $27 \frac{1}{2} \mathrm{G}$ needle in one-tenth volume of $3.8 \%$ sodium citrate to prevent coagulation. Blood was centrifuged at $8,000 \mathrm{~g}$ for $5 \mathrm{~min}$ at room temperature to remove platelets and cellular components. Plasma samples were stored at $-80^{\circ} \mathrm{C}$ until analysis. Brains were perfused with PBS and bisected along the midsagittal plain. One hemisphere was snap frozen and stored at $-80^{\circ} \mathrm{C}$. The other hemisphere was placed in $70 \%$ ethanol, followed by xylene treatment and embedding in paraffin for immunohistochemical and histological analyses.

\section{ELISA analysis of cerebral $A \beta$ peptides}

The pools of $A \beta_{40}$ and $A \beta_{42}$ were determined by using a specific ELISA as previously described [40]. Sequential extraction of pulverized mouse forebrain tissues was as follows. To obtain a soluble fraction, tissue aliquots were homogenized with tris-buffered saline (TBS) $(10 \mu \mathrm{l} / \mathrm{mg}$ tissue) using a bullet blender and $0.5 \mathrm{~mm}$ glass beads (Next Advance, Inc.) followed by 20 min centrifugation at $8,000 \mathrm{~g}$ at $4^{\circ} \mathrm{C}$. The supernatant was removed as the soluble fraction and the pellet was next extracted with $\mathrm{TBS} / 1 \%$ Triton $\mathrm{X}-100$ following the same procedure to obtain a membrane-associated fraction. Finally, the 
resulting pellet was resuspended in $5 \mathrm{M}$ guanidine- $\mathrm{HCl}$ ( $\mathrm{pH}$ 8.0), rotating at room temperature for 3 hours. After centrifugation, the supernatant was removed and kept as the insoluble fraction. Plasma was treated with $5 \mathrm{M}$ guanidine- $\mathrm{HCl}(\mathrm{pH} 8.0)$ at room temperature for 30 min. For each fraction, a sandwich ELISA was performed, where $A \beta_{40}$ and $A \beta_{42}$ were captured using their respective carboxyl terminus-specific antibodies, m2G3 and m21F12, and biotinylated antibody m3D6, specific for human $A \beta$, was used for detection [41].

\section{Immunoblot analysis}

The TBS/1\% Triton X-100 extraction (membrane-associated fraction) was used to detect $\mathrm{A} \beta \mathrm{PP}$ and $\mathrm{A} \beta \mathrm{PP} \mathrm{C}$ terminal fragments (CTFs). Direct TBS/1\% Triton X-100 extraction (total extraction) was used to detect GFAP. Protein concentration was determined using a BCA kit (Pierce). Equal amounts of total protein were separated on 4 to $12 \%$ Tris-Glycine (Invitrogen) or 16\% Tricine (Invitrogen) for APP CTFs. Gels were transferred onto nitrocellulose membranes (Amersham Hybond-ECL). Membranes were blocked with $5 \%$ nonfat milk and incubated overnight at $4{ }^{\circ} \mathrm{C}$ with anti-human $\mathrm{A} \beta \mathrm{PP}$ (mouse mAb P2-1, 1:1000), anti-A PPP-CTF (rabbit pAb, 1:1,000), anti-MMP-9 (Abcam ab38898 1:1,000), anti-neurospecific $\beta$-tubulin (Abcam ab18207 1:2,000), anti-GFAP (Chemicon MAB360 1:1,000). Secondary HRP conjugated anti-mouse or anti-rabbit was used at 1:5,000 dilution. Membranes were developed using ECL (Pierce) and signals were quantified with VersaDoc (BioRad Model 3000).

\section{Immunohistochemical analysis}

$10 \mu \mathrm{m}$ paraffin sections were deparaffinated in xylene and rehydrated with ethanol. Sections were blocked in SuperBlock blocking buffer (Thermo \#37515) with 0.3\% triton X-100 and incubated overnight with diluted primary antibody in 1:10 SuperBlock/PBS containing 0.1\% triton $\mathrm{X}-100$ at $4^{\circ} \mathrm{C}$. The following antibodies were used: $\mathrm{A} \beta$ rabbit $\mathrm{pAb}$ anti-A $\beta 1-28$ 1:500), GFAP antibody (Chemicon MAB360 1:1,000), Keratan sulfate antibody (5D4) (Seikagaku Corp. 1:1,000), OC antibody (a gift from Dr. Charles Glabe, UC Irvine, 1:1,000). Antigen retrieval was done in antigen unmasking solution (Vector labs $\mathrm{H}$ 3301) 30 minutes at $90^{\circ} \mathrm{C}$ for $5 \mathrm{D} 4$ staining and $15 \mathrm{~min}$ in $88 \%$ formic acid for intraneuronal $A \beta(O C)$ staining before blocking. Sections were treated with Alexa Fluor 488 (Invitrogen) for fluorescence staining or biotinylated secondary antibodies followed by vectastain $\mathrm{ABC}$ kit (Vector Labs) for DAB staining.

\section{Gelatin zymography}

Pulverized brain aliquots were homogenized in TBS containing 1\% Triton X-100 as described. After centrifugation, $400 \mu \mathrm{l}$ of supernatant was incubated with $50 \mu \mathrm{l}$
$50 \%$ pre-washed gelatin agarose beads and allowed to rotate overnight at $4^{\circ} \mathrm{C}$. The beads were then pelleted by centrifugation. After removing the supernatant, the beads were washed in PBS and eluted with $50 \mu \mathrm{l} 1 \mathrm{X}$ gel loading dye. Half of the elution was separated on $7.5 \%$ SDS-PAGE containing $0.1 \%$ gelatin. Following electrophoresis, the gels were gently agitated in $2.5 \%$ Triton X100 at room temperature. The buffer was changed every $40 \mathrm{~min}$ for three times. After briefly rinsed in the assay buffer, gels were incubated with shaking in assay buffer (50 mM Tris, $0.2 \mathrm{M} \mathrm{NaCl}, 6.7 \mathrm{mM} \mathrm{CaCl}_{2}$ ) at $37^{\circ} \mathrm{C}$ for 20 hours. Gels were stained with Coomassie blue and destained until clearing by gelatinases was visible.

\section{Statistical analysis}

Data were analyzed using the unpaired two-tailed Student's $t$ test. Error bars represent standard error of the mean (SEM). Significance was taken when $P$ value was less than 0.05 .

\section{Results}

\section{Significant reduction of insoluble cerebral $A \beta$ in Tg-} 5xFAD/MBP ${ }^{-/-}$mice

Previously, we identified MBP as a potent $\mathrm{A} \beta$ fibrillogenesis inhibitor in vitro via a sequence-dependent interaction $[22,29,42]$. To investigate whether the absence of MBP could influence $A \beta$ pathology in vivo, we bred $\mathrm{MBP}^{-1-}$ mice to Tg-5xFAD mice, a model of parenchymal AD-like $\mathrm{A} \beta$ pathology. Age-matched Tg-5xFAD and $\mathrm{Tg}-5 \mathrm{xFAD} / \mathrm{MBP}^{-1-}$ mice were collected at 2 months of age when thioflavin S-positive fibrillar plaques begin to appear in Tg-5xFAD mice [43]. Pulverized brain aliquots were sequentially extracted into soluble $(\mathrm{s})$, membraneassociated $(\mathrm{m})$ and insoluble $(\mathrm{i})$ fractions for $\mathrm{A} \beta$ ELISA analysis. Bigenic $\mathrm{Tg}-5 \mathrm{xFAD} / \mathrm{MBP}^{-/-}$mice had a significant reduction in the amount of insoluble $A \beta$, with an eight-fold reduction in $A \beta_{40}$ and a 30 -fold reduction in $\mathrm{A} \beta_{42}$. No significant differences were found in the levels of soluble $A \beta$ and membrane-associated $A \beta$ between Tg$5 \mathrm{xFAD}$ and $\mathrm{Tg}-5 \mathrm{xFAD} / \mathrm{MBP}^{-/-}$mice (Figure 1 ).

\section{parenchymal $\mathrm{A} \beta$ deposition in Tg-5xFAD/MBP ${ }^{-/-}$mice}

We next performed immunofluorescent labeling for $\mathrm{A} \beta$ on brain sections from Tg-5xFAD and bigenic Tg$5 \mathrm{xFAD} / \mathrm{MBP}^{-1-}$ mice using an anti-A $\beta \mathrm{N}$-terminal antibody. Even though $A \beta$ deposition just begins at this early age in $\mathrm{Tg}-5 \mathrm{xFAD}$ mice, there was a remarkable decrease in both number and the size of $A \beta$ plaques in bigenic $\mathrm{Tg}-5 \mathrm{xFAD} / \mathrm{MBP}^{-/-}$mice observed in the cortex, subiculum, and thalamus (Figure 2), which was consistent with the reduction of insoluble $A \beta$ from the ELISA analysis. 


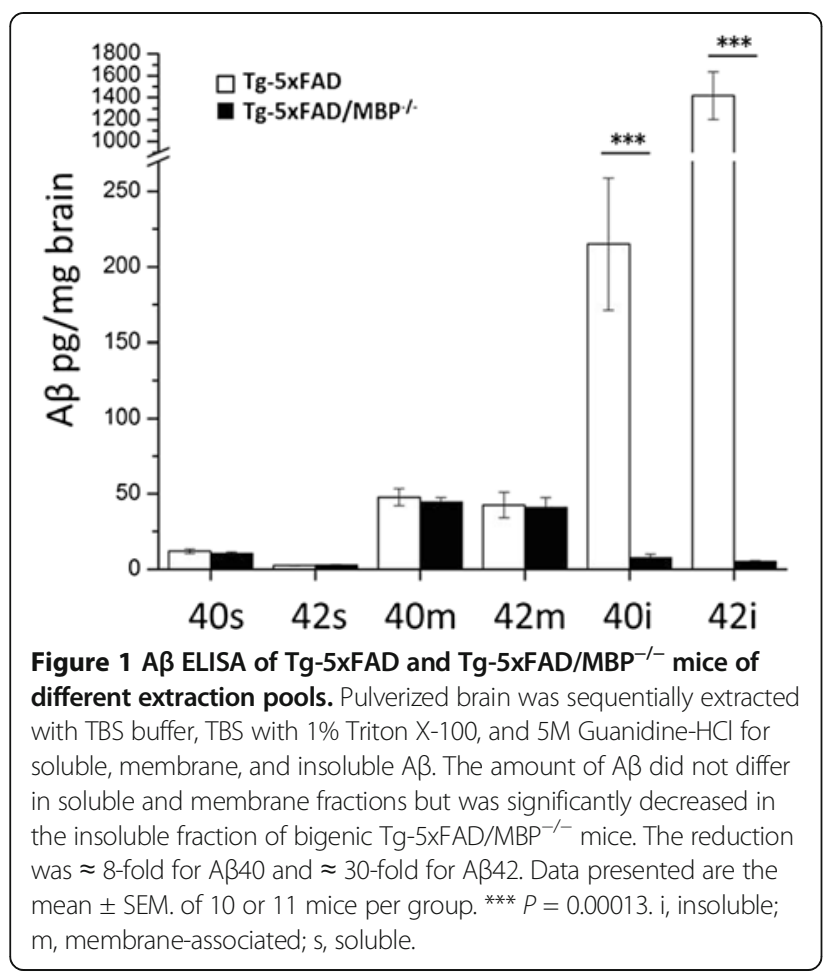

The absence of MBP does not alter human A $\beta P P$ protein levels or processing by $\alpha$ and $\beta$ secretases in Tg-5xFAD mice The observed reduction in $A \beta$ levels and deposition could be a consequence of decreased $A \beta$ production or increased $A \beta$ catabolism. To determine whether the absence of MBP led to a decrease in human A $\beta P P$ expression or processing in Tg-5xFAD mice, we performed quantitative immunoblotting on membrane-associated fractions using antibodies against human $\mathrm{A} \beta \mathrm{PP}$ and the A $\beta$ PP CTFs generated from $\alpha$ secretase $(C 83)$ and $\beta$ secretase cleavages (C99) (Figure 3A). There were no significant differences in the levels of human $\mathrm{A} \beta \mathrm{PP}$, or in the levels of A $\beta P P$ CTF cleavage products, between Tg$5 x F A D$ and $\mathrm{Tg}-5 \mathrm{xFAD} / \mathrm{MBP}^{-/-}$mice (Figure $3 \mathrm{~B}$ ). This finding suggests that the reduction of $A \beta$ in bigenic Tg$5 \mathrm{xFAD} / \mathrm{MBP}^{-1-}$ mice was unlikely to have resulted from decreased $A \beta$ production.

\section{The levels of intracellular $A \beta$ are unaltered between} Tg-5xFAD and Tg-5xFAD/MBP ${ }^{-/}$mice

We next evaluated the level of intracellular $A \beta$ (iA $\beta$ ), since its accumulation is proposed to precede extracellular $A \beta$ deposition and it is suggested as one of the first events in the progression of $A \beta$ pathology $[44,45]$. The detection of iA $\beta$ has been controversial, owing to the cross-reaction of some $A \beta$ antibodies with $A \beta P P$. To avoid this potential confound, we used a conformational antibody (OC), which is specific to a fibrillar epitope present in $\mathrm{A} \beta$ oligomers and fibrils [46]. We saw prominent iA $\beta$-containing neurons in the cortical layer $\mathrm{V}$ that appeared comparable between $\mathrm{Tg}$ 5xFAD and Tg-5xFAD/MBP ${ }^{-/-}$mice (Figures $4 \mathrm{~A}, \mathrm{~B}$ ). The numbers of cortical neurons that were positive with iA $\beta$ were counted (Figure $4 \mathrm{C}$ ). At the age of two months, male mice had three-fold less iA $\beta$ positive neurons than female

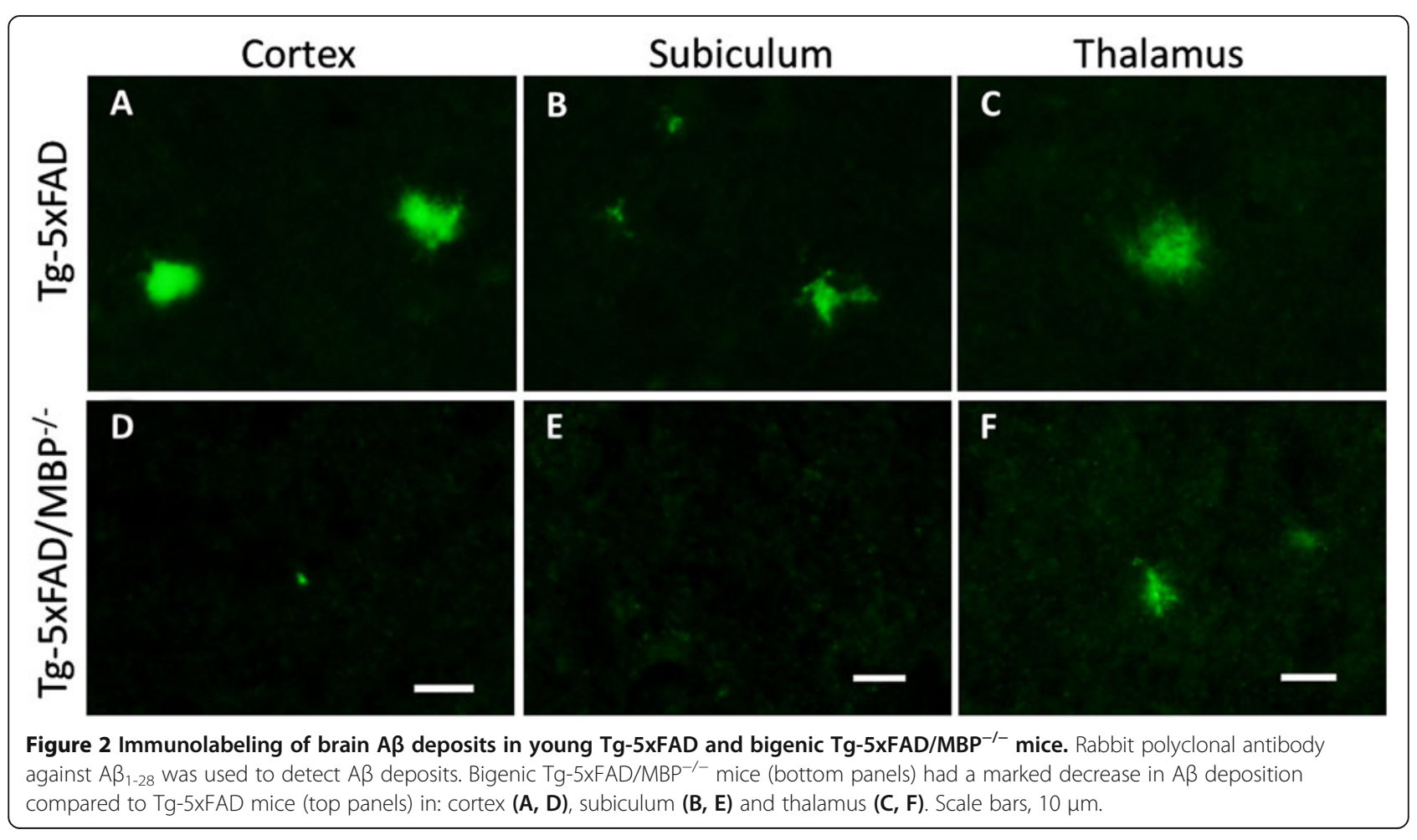




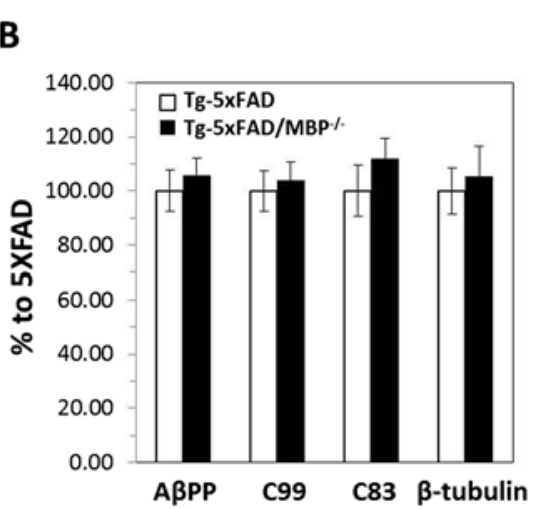

Figure 3 Absence of MBP does not alter AßPP expression or processing in Tg-5xFAD/MBP ${ }^{-1-}$ mice. (A) Equal amount of total protein was separated on 4 to $12 \%$ or Tris-Glycine gel for ABPP or 16\% Tricine for ABPP CTFs. (B) The chemiluminescence signals were quantified and presented as percentage of Tg-5xFAD. Data presented are the mean \pm SEM of 11 or 12 mice per group.

mice, but there was no significant difference between $\mathrm{Tg}$ 5xFAD and Tg-5xFAD/MBP ${ }^{-/-}$mice of the same sex. This result and the quantitative data from Figure 3 together indicate that the absence of MBP does not alter $\mathrm{A} \beta$ production and suggest that the events causing $\mathrm{A} \beta$ reduction in $\mathrm{Tg}-5 \mathrm{xFAD} / \mathrm{MBP}^{-/-}$mice probably occur extracellularly, after $A \beta$ is released.
Efflux of $A \beta$ into plasma or CSF is unaltered in Tg-5xFAD/ $\mathrm{MBP}^{-/-}$mice

Efflux into plasma or CSF represents major clearance pathways for $A \beta$ in brain [47-49]. To determine whether the efflux of $A \beta$ was affected by the absence of MBP, we performed ELISA analyses for $A \beta$ on guanidine-extracted plasma samples and CSF samples obtained from the two
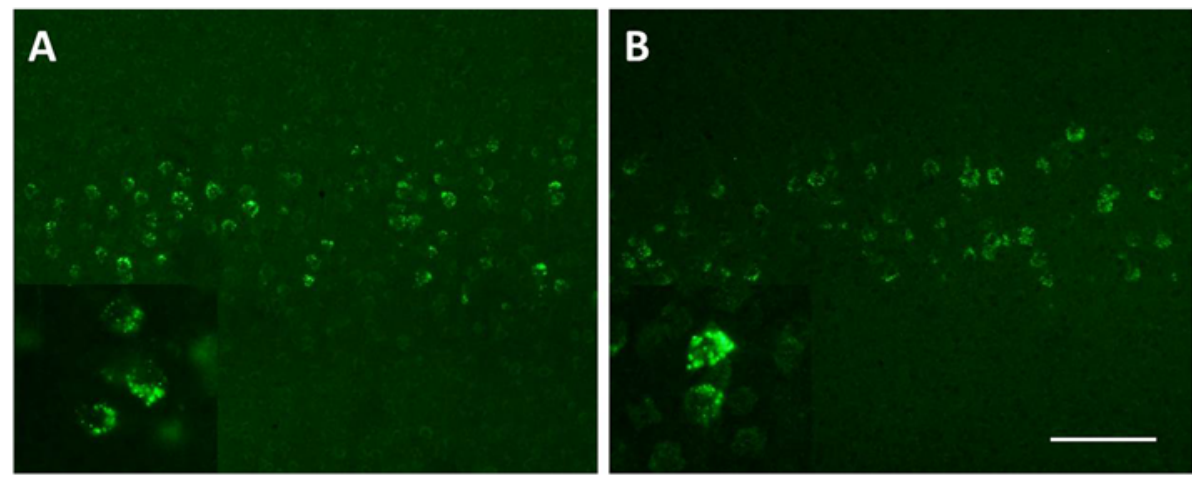

C

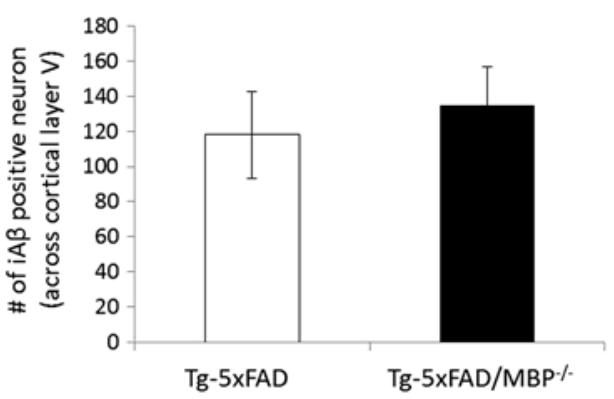

Figure 4 No significant difference in the level of intraneuronal $A \beta$ between Tg-5xFAD and Tg-5xFAD/MBP ${ }^{-/-}$mice. To assess the level of intraneuronal $A \beta$, sections were pretreated with formic acid and incubated with an oligomer specific antibody, OC. Prominent cell body $A \beta$ staining was observed in layer $\mathrm{V}$ of cortex in both (A) Tg-5xFAD and (B) Tg-5xFAD/MBP ${ }^{-1-}$ mice. (C) Cortical neurons with positive iA $\beta$ were counted, no difference was observed between different genotypes. Scale bar, $100 \mu \mathrm{m}$. Data presented are the mean \pm SEM of 4 or 5 mice per group. 
groups of mice. There were similar levels of $A \beta 40$ and $\mathrm{A} \beta 42$ in the plasma of Tg-5xFAD and Tg-5xFAD/MBP ${ }^{-/-}$ mice (Figure 5A). Likewise, in CSF there was no significant difference in the levels of $A \beta 40$ and $A \beta 42$ (Figure 5B). These findings suggest that there is no enhancement of plasma or CSF clearance of $A \beta$ in the absence of MBP.

\section{Elevated neuroinflammatory cells in Tg-5xFAD/MBP ${ }^{-/-}$ mice}

Activated glial cells are known to participate in $A \beta$ clearance by producing a number of $A \beta$ degrading enzymes. Immunostaining for astrocytes using an antibody to GFAP, we found that bigenic Tg-5xFAD/MBP ${ }^{-/-}$mice (Figure $6 \mathrm{C}$ ) had extensive astrocyte staining compared with wild-type mice (Figure 6A) and Tg-5xFAD mice (Figure 6B). In addition, we observed a similar elevated astrocyte immunostaining pattern in the $\mathrm{MBP}^{-/-}$mice (Figure 6D) compared with wild-type mice, as reported previously [50,51]. The elevated GFAP was also confirmed by quantitative immunoblotting on brain homogenates from the different mice (Figure 6E). GFAP levels were increased three- to four-fold in $\mathrm{Tg}-5 \mathrm{xFAD} / \mathrm{MBP}^{-/-}$ mice and $\mathrm{MBP}^{-/-}$mice compared with $\mathrm{Tg}-5 \mathrm{xFAD}$ mice (Figure 6F).

Similarly, using a marker for activated microglia showed increased immunostaining in bigenic Tg-5xFAD/ $\mathrm{MBP}^{-1-}$ mice (Figure 7C) compared with wild-type mice (Figure 7A) and Tg-5xFAD mice (Figure 7B). Again, we observed a similar elevated activated microglial immunostaining pattern in $\mathrm{MBP}^{-/-}$mice (Figure 7D). Together, these findings indicate that bigenic Tg-5xFAD/ $\mathrm{MBP}^{-/-}$mice have elevated levels of neuroinflammatory cells compared with Tg-5xFAD mice and that this effect appears to be associated with the absence of MBP, as $\mathrm{MBP}^{-/-}$mice exhibit comparable increases.
Increased expression of the $A \beta$ degrading enzyme MMP-9 in $\mathrm{Tg}-5 \mathrm{xFAD} / \mathrm{MBP}^{-/-}$mice

Reactive astrocytes and activated microglia are known to express the $\mathrm{A} \beta$-degrading enzymes matrix metalloproteinase 2 and 9 (MMP-2 and MMP-9) [52-54]. To measure the activity of MMP-2 and MMP-9, gelatin zymography was performed using brain lysates prepared from $\mathrm{Tg}$ $5 x F A D$ mice and bigenic $\mathrm{Tg}-5 \mathrm{xFAD} / \mathrm{MBP}^{-/-}$mice that were concentrated by filtration over gelatin agarose. Gelatin zymography showed a two-fold increase in MMP-9, but not MMP-2, in Tg-5xFAD/MBP ${ }^{-/-}$mice compared with Tg-5xFAD mice (Figure 8A,B). Immunoblotting showed a similar increase in MMP-9 protein levels in Tg-5xFAD $/ \mathrm{MBP}^{-/-}$mice (Figure $8 \mathrm{C}$ ).

\section{Discussion}

The assembly pathway of endogenous $A \beta$ is influenced by various $A \beta$ chaperone proteins, which can either promote or inhibit the aggregation of $\mathrm{A} \beta$. Previously, our in vitro work showed that MBP could strongly bind fibrillogenic forms of $A \beta$ and potently inhibit their assembly into fibrils $[22,29]$. Although MBP is largely embedded in myelin sheaths, it can be readily detected in the CSF of healthy individuals within the range of $\mu \mathrm{g} / \mathrm{l}[55,56]$. Furthermore, after brain injuries and myelin breakdown, the MBP is increased in the CSF $[55,57,58]$. Golli-MBP proteins are expressed in several cell types in the CNS, including oligodendrocytes, neurons, and microglia [59-61]. Recent studies have implicated Golli-MBP proteins as multifunctional intracellular scaffolds that can bind a number of intracellular proteins and small molecule ligands affecting diverse cellular processes [62]. These findings suggest that cells that express Golli-MBP proteins could affect intracellular, and possibly extracellular, $A \beta$ assembly, molecular interactions, and associated pathogenic effects. Thus with its abundance in the brain and its close proximity to $A \beta$ it is
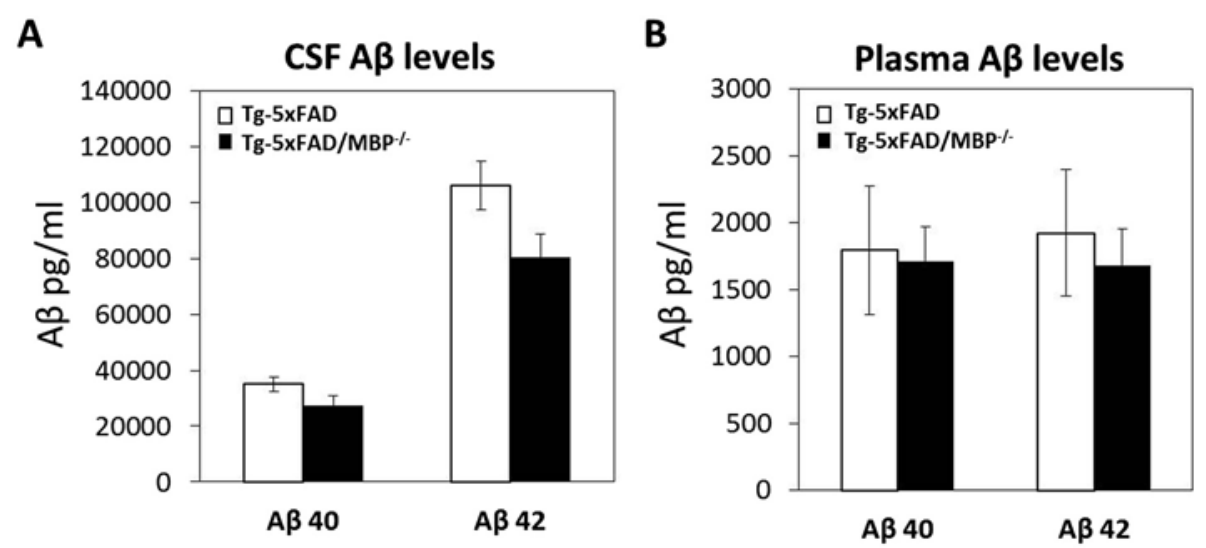

Figure 5 No significant difference in plasma and CSF $A \beta$ levels of Tg-5xFAD and Tg-5xFAD/MBP ${ }^{-/-}$mice. ELISA measurements were performed for A 40 and A 42 in plasma samples (A) and CSF samples (B) collected from Tg-5xFAD and Tg-5xFAD/MBP ${ }^{-/-}$mice. The data presented are the mean \pm SEM of ten mice per group. 


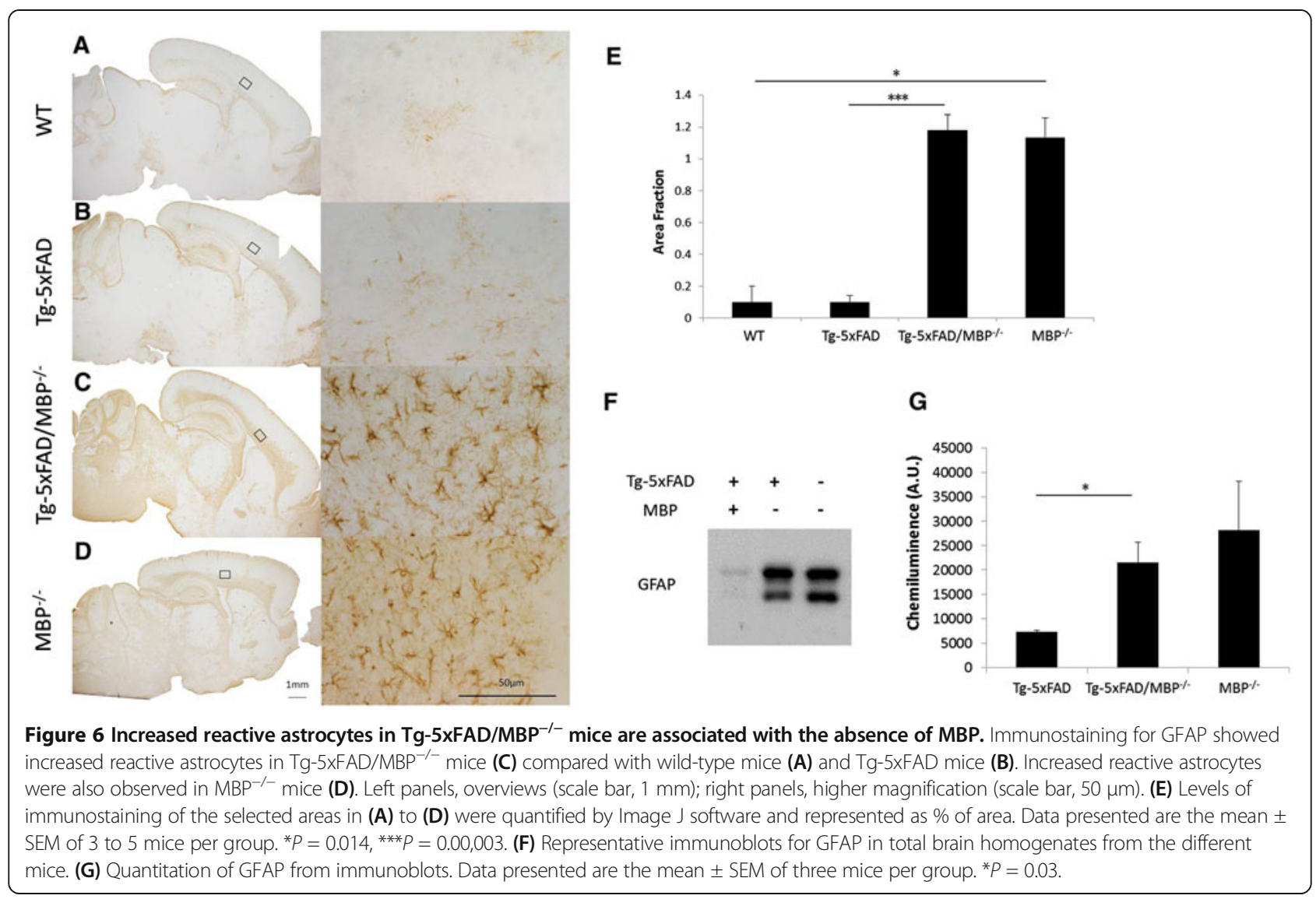

possible that MBP could influence $A \beta$ levels, especially at early stages of myelin breakdown.

In this present study, we sought to explore the consequences of removing endogenous MBP on $A \beta$ accumulation in transgenic mice. To do this, we generated $\mathrm{Tg}$ $5 \mathrm{xFAD} / \mathrm{MBP}^{-/-}$mice by breeding $\mathrm{MBP}^{-/-}$mice to $\mathrm{Tg}$ 5xFAD mice, a model of early-onset parenchymal $A \beta$ pathology. Owing to the short life span of $\mathrm{MBP}^{-/-}$mice [63], the choice of an aggressive $A \beta$ depositing mouse model such as Tg-5xFAD was necessary to allow us to investigate $A \beta$ pathology at a young age. At weaning age, the bigenic Tg-5xFAD/ $\mathrm{MBP}^{-1-}$ mice exhibited the same severe shivering phenotype that is characteristic of the $\mathrm{MBP}^{-/-}$ mice, but died at a younger age before reaching three months, which we suspected to be a result of the rapid $A \beta$ accumulation from the FAD mutations.

Based on our earlier in vitro data, showing a potent inhibitory effect of MBP on $A \beta$ fibril assembly, we might have expected to see an increase in $A \beta$ accumulation and deposition in the absence of MBP. Conversely, in the absence of MBP the Tg-5xFAD mice exhibited significantly decreased $A \beta$ levels and $A \beta$ deposition in the brain at two months of age (Figure 1 and Figure 2, respectively). However, this finding was not unique to $\mathrm{Tg}-5 \mathrm{xFAD} / \mathrm{MBP}^{-/-}$mice. We bred Tg-SwDI mice, another model of early-onset $A \beta$ accumulation and deposition, with $\mathrm{MBP}^{-/-}$mice. Like bigenic $\mathrm{Tg}-5 \mathrm{xFAD} / \mathrm{MBP}^{-/-}$mice, bigenic $\mathrm{Tg}$-SwDI/ $\mathrm{MBP}^{-1-}$ mice also exhibited decreased $\mathrm{A} \beta$ levels and $\mathrm{A} \beta$ deposition at 2 to 3 months of age (data not shown).

A lowering of cerebral $A \beta$ levels can result from reduced expression of $\mathrm{A} \beta \mathrm{PP}$ and production of the peptide. However, the levels of A $\beta$ PP protein, A $\beta$ PP CTFs and the presence of intraneuronal $A \beta$ were similar in the brains of Tg-5xFAD mice and bigenic $\mathrm{Tg}-5 \mathrm{xFAD} / \mathrm{MBP}^{-/-}$mice, suggesting that the reductions in $A \beta$ were not the consequence of decreased production in the absence of MBP. Alternatively, $A \beta$ reductions in the brain can arise, owing to increased clearance through established efflux pathways. For example, through one route $A \beta$ initially released by neurons enters the interstitial fluid, which drains to the CSF [48]. Yet another mechanism involves active transport of $A \beta$ across the blood-brain barrier into the circulation that is mediated by known $A \beta$ receptors, including lowdensity lipoprotein receptor-related protein 1 (LRP1) and P-glycoprotein $[64,65]$. However, we found no increase in the levels of $A \beta$ in the CSF or plasma of bigenic Tg$5 \times \mathrm{FAD} / \mathrm{MBP}^{-/-}$mice, arguing against increased $\mathrm{A} \beta$ efflux in the absence of MBP.

Another recognized clearance mechanism of $A \beta$ in brain involves a broad class of $A \beta$-degrading enzymes 


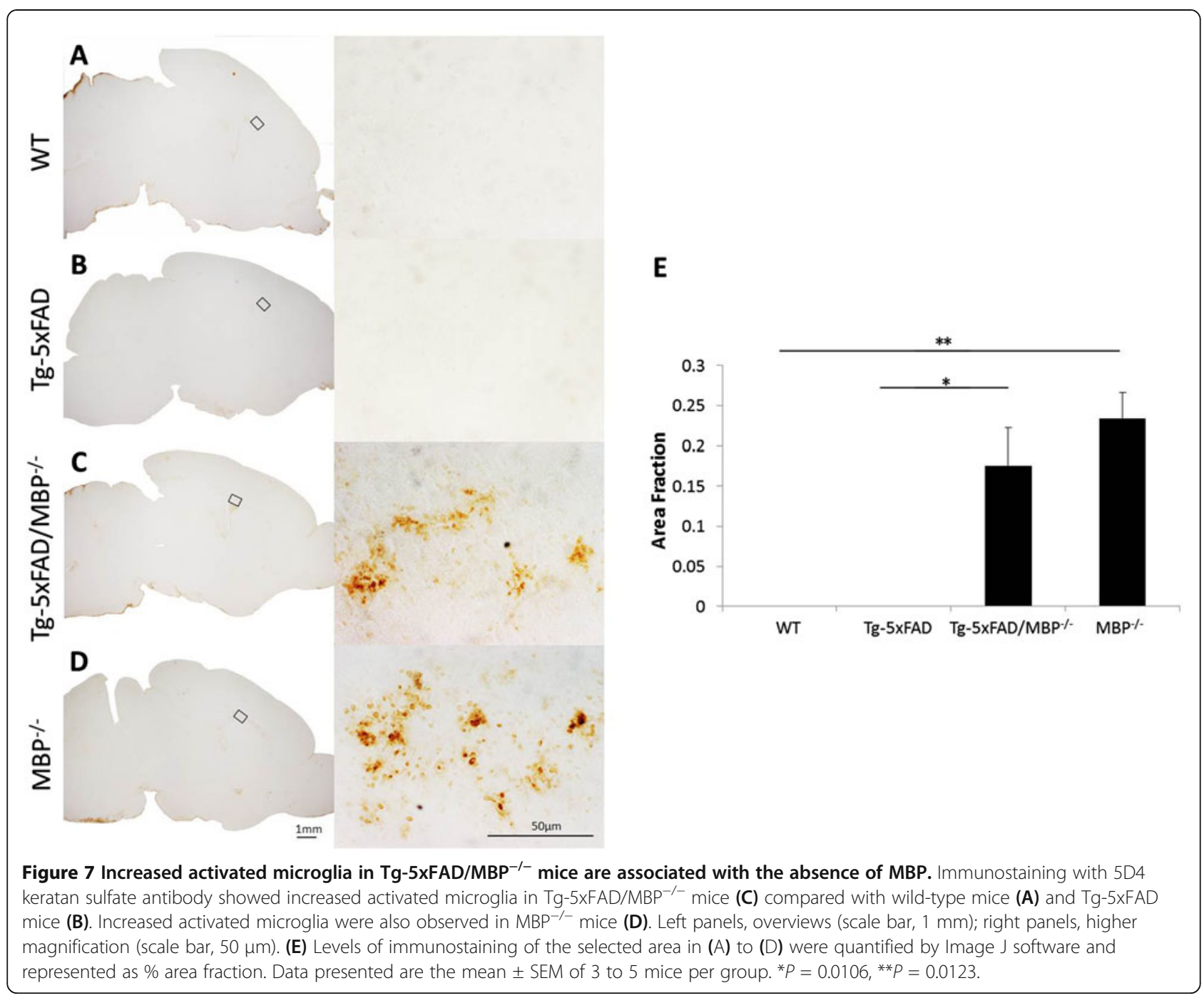

that are largely released by activated neuroinflammatory cells [66]. In the bigenic $\mathrm{Tg}-5 \mathrm{xFAD} / \mathrm{MBP}^{-/-}$mice, we found markedly elevated staining for reactive astrocytes and activated microglia compared with $\mathrm{Tg}-5 \mathrm{xFAD}$ mice (Panels $\mathrm{C}$ of Figures 6 and 7). Once Tg-5xFAD mice age and develop numerous fibrillar $A \beta$ plaques, they exhibit a robust neuroinflammatory response to these plaques that is characterized by reactive astrocytes and activated microglia [38]. Yet, in our study the young animals at two months of age are just beginning to develop amyloid plaques and neuroinflammatory cells are scarce or absent (Panels B of Figures 6 and 7). Furthermore, the increased immunostaining of activated glial markers in bigenic $\mathrm{Tg}-5 \mathrm{xFAD} / \mathrm{MBP}^{-/-}$mice was not observed around the few plaques that had developed. However, the increase in neuroinflammatory cells was similarly observed in the $\mathrm{MBP}^{-/}$mice alone (Panels D of Figures 6 and 7); this is consistent with previous reports regarding these mice [51]. Activation of glial cells is a common phenomenon in neurodegenerative diseases, including $\mathrm{AD}$, multiple sclerosis, and traumatic brain injury. A number of other mouse models with deficiencies in myelination from different causes including jimpy, $M B P^{m l d}$, and quaking were all found to exhibit glial activation $[67,68]$. Although it is not well understood, the increase in neuroinflammatory cells observed in the $\mathrm{MBP}^{-/-}$mice appears to be a pleiotropic effect due to the loss of MBP and abnormal myelination, thereby disrupting normal interaction between glial cells. Indeed, it has been suggested that a proliferation of mixed-phenotype glial cells, which were found to be increased in the pathogenic white matter, contribute to this gliosis in $\mathrm{MBP}^{-/-}$mice [69].

In any case, reactive astrocytes and activated microglia both produce MMP-2 and MMP-9 in a number of CNS disorders, including $\mathrm{AD}$ and multiple sclerosis [70-73]. In regards to A $\beta$-degrading enzymes, MMP-2 and MMP-9 are distinctive in that both can degrade soluble $A \beta$ peptides and fibrillar plaque $A \beta$ [74-78]. While we did not 
A

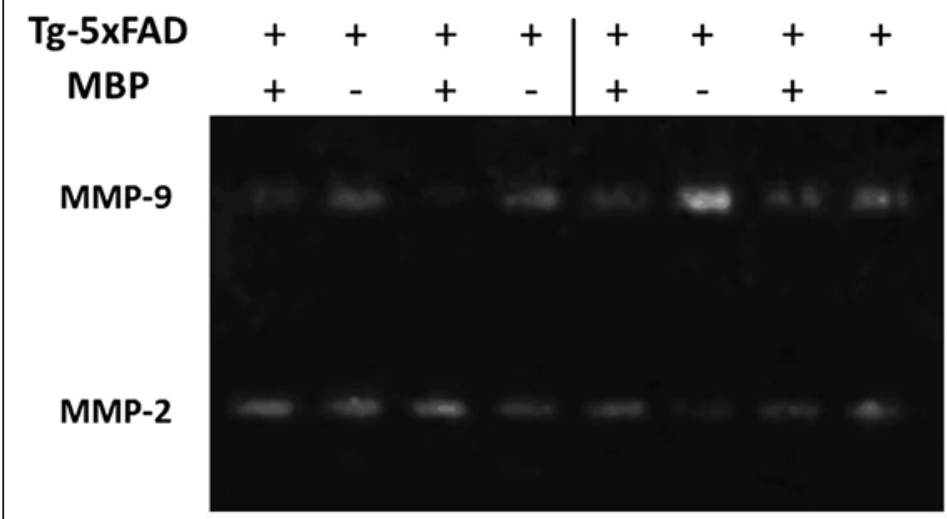

C

MMP-9
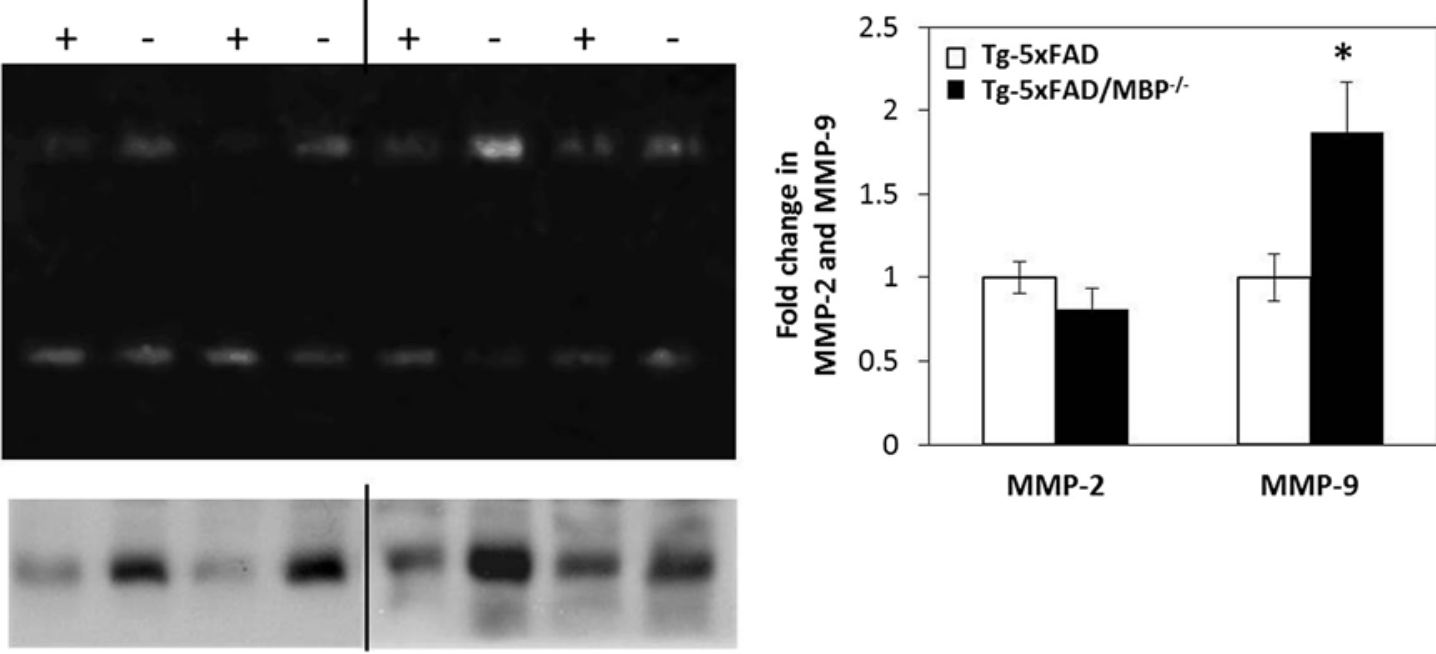

Figure 8 Elevated MMP-9 levels in Tg-5xFAD/MBP ${ }^{-/-}$mice. (A) Gelatin zymography of brain homogenates shows increased levels of MMP-9, but not MMP-2, in bigenic Tg-5xFAD/MBP ${ }^{-/-}$mice. (B) Quantification of gelatin zymography signals show MMP-9, but not MMP-2, was increased 2-fold in bigenic Tg-5xFAD-MBP ${ }^{-1-}$ mice. Data presented are mean \pm SEM of four mice per group. ${ }^{*} p<0.05$. (C) Immunoblot of MMP-9 in brain homogenates of Tg-5xFAD mice and bigenic $\mathrm{Tg}-5 \mathrm{xFAD} / \mathrm{MBP}^{-1-}$ mice.

find elevated MMP-2 levels in the brains of bigenic Tg$5 \mathrm{xFAD} / \mathrm{MBP}^{-1-}$ mice, we did observe a significant increase in MMP-9 levels, as assessed by zymography and immunoblotting (Figure 8). Although it is possible that other $A \beta-$ degrading enzymes could be elevated in Tg-5xFAD/ $\mathrm{MBP}^{-/-}$ mice, quantitative PCR analysis did not reveal increased expression of some of the more common enzymes including insulin-degrading enzyme, neprilysin, or angiotensinconverting enzyme (data not shown). This suggests that elevated MMP-9, produced by reactive astrocytes and activated microglia as a consequence of the absence of MBP, could contribute to the decreased $A \beta$ levels observed in Tg-5xFAD $/ \mathrm{MBP}^{-/-}$mice.

A goal of this study was to investigate the potential consequences of MBP-A $\beta$ interactions in the brain. Based on our previous in vitro work showing that MBP strongly binds $A \beta$ and inhibits fibrillar assembly [22,29,42], one prediction is that in the absence of MBP there could be greater accumulation of fibrillar $\mathrm{A} \beta$. On the contrary, as shown here, in the complete absence of MBP there was a significant reduction in the accumulation of $A \beta$. However, the $\mathrm{A} \beta$ reduction observed in the bigenic $\mathrm{Tg}-5 \mathrm{xFAD} /$ $\mathrm{MBP}^{-1-}$ mice is more likely to be an indirect pleiotropic effect of the absence of MBP and proper myelination, leading to glial activation and increased $A \beta$ degrading enzymes, rather than a consequence of the direct loss of interaction between MBP and A $\beta$. Recently, we identified specific residues in MBP that are essential for $A \beta$ binding and fibril assembly inhibition [79]. To overcome the significant limitations of $\mathrm{MBP}^{-/-}$mice, future efforts are focused on utilizing novel mice that harbor specific mutations of the residues in $\mathrm{MBP}$ involved in $\mathrm{A} \beta$ binding and fibril inhibition. In contrast with the $\mathrm{MBP}^{-/-}$mice, these new mutant MBP mice are largely expected to retain normal physiological functions of MBP but will be devoid of the ability to interact with $\mathrm{A} \beta$. Alternatively, efforts are also focused on characterizing novel transgenic mice that over-express biologically active fragment of MBP in brain. Together, the novel MBP knock-in mutant mice and MBP-expressing transgenic mice, crossed with $\mathrm{A} \beta \mathrm{PP}$ transgenic mice, will provide more suitable models for studying in vivo MBP$\mathrm{A} \beta$ relationships, thereby enabling us to gain insight into $\mathrm{A} \beta$ assembly in brain and a potential therapeutic role of MBP as an $\mathrm{A} \beta$ fibril assembly inhibitor.

\section{Conclusions}

The primary findings of this study show that in the absence of MBP there is decreased accumulation and deposition of $A \beta$ in Tg-5xFAD mice. The decrease in $A \beta$ was not a consequence of reduced $A \beta P P$ expression or processing or of increased peptide clearance through plasma and CSF efflux pathways. However, there were elevated reactive astrocytes and microglia accompanied by increased expression of $\mathrm{A} \beta$-degrading enzyme MMP9 in bigenic $\mathrm{Tg}-5 \mathrm{xFAD} / \mathrm{MBP}^{-/-}$mice. The absence of MBP promotes a neuroinflammatory environment that can reduce $A \beta$ accumulation in the brains of transgenic mice. 


\section{Abbreviations}

AßPP: amyloid precursor protein; $A \beta$ : amyloid beta protein;

apoE: apolipoprotein E; MBP: myelin basic protein; C83: C-terminal fragment of AßPP generated by a secretase cleavage; C99: C-terminal fragment of A $\beta P P$ generated by $\beta$ secretase cleavage; CNS: central nervous system; CSF: cerebrospinal fluid; CTF: C-terminal fragment; ELISA: enzyme-linked immunosorbent assay; GFAP: glial fibrillary acidic protein; iA 3 : intracellular amyloid beta protein; MBP: myelin basic protein; MMP: matrix metalloproteinase; OC: a fibril specific, conformation dependent antibody used in intracellular A $\beta$ detection; PBS: phosphate-buffered saline; SEM: standard error of the mean; TBS: tris-buffered saline.

\section{Competing interests}

Both authors declare that they have no competing interests.

\section{Authors' contributions}

MO designed, performed experiments and analyzed the data. WEVN obtained funding, helped conceive the project and interpreted data. Both authors read and approved the final manuscript.

\section{Acknowledgements}

This work was supported in part by National Institutes of Health grants R21-NS079951 and R21-AG039215. Antibody reagents for the AB ELISAs were generously provided by Lilly Research Laboratories.

Received: 2 August 2013 Accepted: 27 September 2013 Published: 5 November 2013

\section{References}

1. Vassar R, Bennett BD, Babu-Khan S, Kahn S, Mendiaz EA, Denis P, Teplow DB, Ross S, Amarante P, Loeloff R, Luo Y, Fisher S, Fuller J, Edenson S, Lile J, Jarosinski MA, Biere AL, Curran E, Burgess T, Louis JC, Collins F, Treanor J, Rogers G, Citron $M$ : $\beta$-secretase cleavage of Alzheimer's amyloid precursor protein by the transmembrane aspartic protease BACE. Science 1999, 286:735-741.

2. De Strooper B, Saftig P, Craessaerts K, Vanderstichele H, Guhde G, Annaert W, Von Figura K, Van Leuven F: Deficiency of presenilin-1 inhibits the normal cleavage of amyloid precursor protein. Nature 1998, 391:387-390.

3. Edbauer D, Winkler E, Regula JT, Pesold B, Steiner H, Haass C: Reconstitution of $\gamma$-secretase activity. Nat Cell Biol 2003, 5:486-488.

4. Benilova I, Karran E, De Strooper B: The toxic a oligomer and Alzheimer's disease: an emperor in need of clothes. Nat Neurosci 2012, 15:349-357.

5. Haass $C$, Selkoe DJ: Soluble protein oligomers in neurodegeneration: lessons from the Alzheimer's amyloid $\beta$-peptide. Nat Rev Mol Cell Biol 2007, 8:101-112

6. Selkoe DJ: Soluble oligomers of the amyloid $\beta$-protein impair synaptic plasticity and behavior. Behav Brain Res 2008, 192:106-113.

7. Urbanc B, Cruz L, Le R, Sanders J, Ashe KH, Duff K, Stanley HE, Irizarry MC, Hyman BT: Neurotoxic effects of thioflavin S-positive amyloid deposits in transgenic mice and Alzheimer's disease. Proc Natl Acad Sci USA 2002, 99:13990-13995.

8. McLellan ME, Kajdasz ST, Hyman BT, Bacskai BJ: In vivo imaging of reactive oxygen species specifically associated with thioflavine S-positive amyloid plaques by multiphoton microscopy. J Neurosci 2003, 23:2212-2217.

9. Strittmatter WJ, Saunders AM, Schmechel D, Pericak-Vance M, Enghild J, Salvesen GS, Roses AD: Apolipoprotein E: high-avidity binding to betaamyloid and increased frequency of type 4 allele in late-onset familial Alzheimer disease. Proc Natl Acad Sci USA 1993, 90:1977-1981.

10. LaDu MJ, Falduto MT, Manelli AM, Reardon CA, Getz GS, Frail DE: Isoformspecific binding of apolipoprotein E to beta-amyloid. J Biol Chem 1994, 269:23403-23406.

11. Holtzman DM: Role of apoE/A $\beta$ interactions in the pathogenesis of Alzheimer's disease and cerebral amyloid angiopathy. J Mol Neurosci 2001, 17:147-155.

12. Matsubara E, Frangione B, Ghiso J: Characterization of apolipoprotein J-Alzheimer's A $\beta$ interaction. J Biol Chem 1995, 270:7563-7567.

13. DeMattos RB, O'Dell MA, Parsadanian M, Taylor JW, Harmony JA, Bales KR, Paul SM, Aronow BJ, Holtzman DM: Clusterin promotes amyloid plaque formation and is critical for neuritic toxicity in a mouse model of Alzheimer's disease. Proc Natl Acad Sci USA 2002, 99:10843-10848.
14. Magrane J, Smith RC, Walsh K, Querfurth HW: Heat shock protein 70 participates in the neuroprotective response to intracellularly expressed $\beta$-amyloid in neurons. J Neurosci 2004, 24:1700-1706.

15. Evans CG, Wisen S, Gestwicki JE: Heat shock proteins 70 and 90 inhibit early stages of amyloid $\beta-(1-42)$ aggregation in vitro. J Biol Chem 2006, 281:33182-33191

16. Yamamoto N, Hirabayashi $Y$, Amari M, Yamaguchi H, Romanov G, Van Nostrand WE, Yanagisawa K: Assembly of hereditary amyloid $\beta$-protein variants in the presence of favorable gangliosides. FEBS Lett 2005, 579:2185-2190.

17. Schwarzman AL, Goldgaber D: Interaction of transthyretin with amyloid $\beta$-protein: binding and inhibition of amyloid formation. Ciba Found Symp 1996, 199:146-160. discussion 160-144.

18. Buxbaum JN, Ye Z, Reixach N, Friske L, Levy C, Das P, Golde T, Masliah E, Roberts AR, Bartfai T: Transthyretin protects Alzheimer's mice from the behavioral and biochemical effects of a $\beta$ toxicity. Proc Natl Acad Sci USA 2008, 105:2681-2686.

19. van Horssen J, Wesseling $P$, van den Heuvel LP, de Waal RM, Verbeek MM: Heparan sulphate proteoglycans in Alzheimer's disease and amyloidrelated disorders. Lancet Neurol 2003, 2:482-492.

20. Yanagisawa $K$, Odaka A, Suzuki N, Ihara Y: GM1 ganglioside-bound amyloid $\beta$-protein $(A \beta)$ : a possible form of preamyloid in Alzheimer's disease. Nat Med 1995, 1:1062-1066.

21. Chi EY, Frey SL, Lee KY: Ganglioside G(M1)-mediated amyloid-beta fibrillogenesis and membrane disruption. Biochemistry 2007, 46:1913-1924.

22. Hoos MD, Ahmed M, Smith SO, Van Nostrand WE: Inhibition of familial cerebral amyloid angiopathy mutant amyloid $\beta$-protein fibril assembly by myelin basic protein. J Biol Chem 2007, 282:9952-9961.

23. Boggs JM: Myelin basic protein: a multifunctional protein. Cell Mol Life Sci 2006, 63:1945-1961.

24. Campagnoni AT, Pribyl TM, Campagnoni CW, Kampf K, Amur-Umarjee S, Landry CF, Handley WW, Newman SL, Garbay B, Kitamura K: Structure and developmental regulation of Golli-mbp, a 105-kilobase gene that encompasses the myelin basic protein gene and is expressed in cells in the oligodendrocyte lineage in the brain. J Biol Chem 1993, 268:4930-4938.

25. Kamholz J, de Ferra F, Puckett C, Lazzarini R: Identification of three forms of human myelin basic protein by cDNA cloning. Proc Natl Acad Sci USA 1986, 83:4962-4966.

26. Roth HJ, Kronquist KE, Kerlero De Rosbo N, Crandall BF, Campagnoni AT: Evidence for the expression of four myelin basic protein variants in the developing human spinal cord through cDNA cloning. J Neurosci Res 1987, 17:321-328.

27. Harauz G, Ishiyama N, Hill CM, Bates IR, Libich DS, Fares C: Myelin basic protein-diverse conformational states of an intrinsically unstructured protein and its roles in myelin assembly and multiple sclerosis. Micron 2004, 35:503-542.

28. de Ferra F, Engh $H$, Hudson L, Kamholz J, Puckett C, Molineaux S, Lazzarin RA: Alternative splicing accounts for the four forms of myelin basic protein. Cell 1985, 43:721-727.

29. Hoos MD, Ahmed M, Smith SO, Van Nostrand WE: Myelin basic protein binds to and inhibits the fibrillar assembly of $A \beta 42$ in vitro. Biochemistry 2009, 48:4720-4727.

30. Bartzokis G, Lu PH, Geschwind DH, Edwards N, Mintz J, Cummings JL: Apolipoprotein $\mathrm{E}$ genotype and age-related myelin breakdown in healthy individuals: implications for cognitive decline and dementia. Arch Gen Psychiatry 2006, 63:63-72.

31. Liu MC, Akle V, Zheng W, Kitlen J, O'Steen B, Larner SF, Dave JR, Tortella FC, Hayes RL, Wang KK: Extensive degradation of myelin basic protein isoforms by calpain following traumatic brain injury. J Neurochem 2006, 98:700-712.

32. Bartzokis G, Lu PH, Geschwind DH, Tingus K, Huang D, Mendez MF, Edwards $\mathrm{N}$, Mintz J: Apolipoprotein E affects both myelin breakdown and cognition: implications for age-related trajectories of decline into dementia. Biol Psychiatry 2007, 62:1380-1387.

33. Bartzokis G, Sultzer D, Lu PH, Nuechterlein KH, Mintz J, Cummings لـ: Heterogeneous age-related breakdown of white matter structural integrity: implications for cortical 'disconnection' in aging and Alzheimer's disease. Neurobiol Aging 2004, 25:843-851.

34. Marner L, Nyengaard JR, Tang Y, Pakkenberg B: Marked loss of myelinated nerve fibers in the human brain with age. J Comp Neurol 2003, 462:144-152.

35. Roher AE, Weiss N, Kokjohn TA, Kuo YM, Kalback W, Anthony J, Watson D, Luehrs DC, Sue L, Walker D, Emmerling M, Goux W, Beach T: Increased A $\beta$ 
peptides and reduced cholesterol and myelin proteins characterize white matter degeneration in Alzheimer's disease. Biochemistry 2002, 41:11080-11090.

36. Mitew S, Kirkcaldie MT, Halliday GM, Shepherd CE, Vickers JC, Dickson TC Focal demyelination in Alzheimer's disease and transgenic mouse models. Acta Neuropathol 2010, 119:567-577.

37. Molineaux SM, Engh H, de Ferra F, Hudson L, Lazzarini RA: Recombination within the myelin basic protein gene created the dysmyelinating shiverer mouse mutation. Proc Natl Acad Sci USA 1986, 83:7542-7546.

38. Oakley H, Cole SL, Logan S, Maus E, Shao P, Craft J, Guillozet-Bongaarts A, Ohno M, Disterhoft J, Van Eldik L, Berry R, Vassar R: Intraneuronal $\beta$-amyloid aggregates, neurodegeneration, and neuron loss in transgenic mice with five familial Alzheimer's disease mutations: potential factors in amyloid plaque formation. J Neurosci 2006, 26:10129-10140.

39. Liu L, Duff K: A technique for serial collection of cerebrospinal fluid from the cisterna magna in mouse. J Vis Exp 2008, 21:960.

40. Davis J, Xu F, Deane R, Romanov G, Previti ML, Zeigler K, Zlokovic BV, Van Nostrand WE: Early-onset and robust cerebral microvascular accumulation of amyloid $\beta$-protein in transgenic mice expressing low levels of a vasculotropic Dutch/lowa mutant form of amyloid $\beta$-protein precursor. J Biol Chem 2004, 279:20296-20306.

41. DeMattos RB, Bales KR, Parsadanian M, O'Dell MA, Foss EM, Paul SM, Holtzman DM: Plaque-associated disruption of CSF and plasma amyloid- $\beta(A \beta)$ equilibrium in a mouse model of Alzheimer's disease. J Neurochem 2002, 81:229-236.

42. Liao MC, Hoos MD, Aucoin D, Ahmed M, Davis J, Smith SO, Van Nostrand WE: N-terminal domain of myelin basic protein inhibits amyloid $\beta$-protein fibril assembly. J Biol Chem 2010, 285:35590-35598.

43. Oddo S, Billings L, Kesslak JP, Cribbs DH, LaFerla FM: A $\beta$ immunotherapy leads to clearance of early, but not late, hyperphosphorylated tau aggregates via the proteasome. Neuron 2004, 43:321-332.

44. Gyure KA, Durham R, Stewart WF, Smialek JE, Troncoso JC: Intraneuronal a $\beta$-amyloid precedes development of amyloid plaques in Down syndrome. Arch Pathol Lab Med 2001, 125:489-492.

45. Wirths O, Multhaup G, Czech C, Blanchard V, Moussaoui S, Tremp G, Pradier $L$, Beyreuther K, Bayer TA: Intraneuronal a $\beta$ accumulation precedes plaque formation in $\beta$-amyloid precursor protein and presenilin-1 doubletransgenic mice. Neurosci Lett 2001, 306:116-120.

46. Kayed R, Head E, Sarsoza F, Saing T, Cotman CW, Necula M, Margol L, Wu J, Breydo L, Thompson JL, Rasool S, Gurlo T, Butler P, Glabe CG: Fibril specific, conformation dependent antibodies recognize a generic epitope common to amyloid fibrils and fibrillar oligomers that is absent in prefibrillar oligomers. Mol Neurodegener 2007, 2:18.

47. Shibata M, Yamada S, Kumar SR, Calero M, Bading J, Frangione B, Holtzman DM, Miller CA, Strickland DK, Ghiso J, Zlokovic BV: Clearance of Alzheimer's amyloid-ss(1-40) peptide from brain by LDL receptor-related protein-1 at the blood-brain barrier. J Clin Invest 2000, 106:1489-1499.

48. Silverberg GD, Mayo M, Saul T, Rubenstein E, McGuire D: Alzheimer's disease, normal-pressure hydrocephalus, and senescent changes in CSF circulatory physiology: a hypothesis. Lancet Neurol 2003, 2:506-511.

49. Zlokovic BV: Clearing amyloid through the blood-brain barrier. J Neurochem 2004, 89:807-811.

50. Privat A, Jacque C, Bourre JM, Dupouey P, Baumann N: Absence of the major dense line in myelin of the mutant mouse 'shiverer'. Neurosci Lett 1979, 12:107-112.

51. Nagaike K, Mikoshiba K, Tsukada Y: Dysmyelination of shiverer mutant mice in vivo and in vitro. J Neurochem 1982, 39:1235-1241.

52. Gottschall $P E, Y u X$, Bing $B$ : Increased production of gelatinase $B$ (matrix metalloproteinase- 9 ) and interleukin- 6 by activated rat microglia in culture. J Neurosci Res 1995, 42:335-342.

53. Muir EM, Adcock KH, Morgenstern DA, Clayton R, von Stillfried N, Rhodes K, Ellis C, Fawcett JW, Rogers JH: Matrix metalloproteases and their inhibitors are produced by overlapping populations of activated astrocytes. Brain Res Mol Brain Res 2002, 100:103-117.

54. Sbai O, Ould-Yahoui A, Ferhat L, Gueye Y, Bernard A, Charrat E, Mehanna A, Risso JJ, Chauvin JP, Fenouillet E, Rivera S, Khrestchatisky M: Differential vesicular distribution and trafficking of MMP-2, MMP-9, and their inhibitors in astrocytes. Glia 2010, 58:344-366.

55. Beems T, Simons KS, Van Geel WJ, De Reus HP, Vos PE, Verbeek MM: Serum- and CSF-concentrations of brain specific proteins in hydrocephalus. Acta Neurochir (Wien) 2003, 145:37-43.
56. Abdo WF, van de Warrenburg BP, Munneke M, van Geel WJ, Bloem BR, Kremer HP, Verbeek MM: CSF analysis differentiates multiple-system atrophy from idiopathic late-onset cerebellar ataxia. Neurology 2006 67:474-479.

57. Su E, Bell MJ, Kochanek PM, Wisniewski SR, Bayir H, Clark RS, Adelson PD, Tyler-Kabara EC, Janesko-Feldman KL, Berger RP: Increased CSF concentrations of myelin basic protein after TBI in infants and children: absence of significant effect of therapeutic hypothermia. Neurocrit Care 2012, 17:401-407.

58. Lamers KJ, de Reus HP, Jongen PJ: Myelin basic protein in CSF as indicator of disease activity in multiple sclerosis. Mult Scler 1998, 4:124-126.

59. Landry CF, Ellison JA, Pribyl TM, Campagnoni C, Kampf K, Campagnoni AT: Myelin basic protein gene expression in neurons: developmental and regional changes in protein targeting within neuronal nuclei, cell bodies, and processes. J Neurosci 1996, 16:2452-2462.

60. Landry CF, Pribyl TM, Ellison JA, Givogri MI, Kampf K, Campagnoni CW, Campagnoni AT: Embryonic expression of the myelin basic protein gene: identification of a promoter region that targets transgene expression to pioneer neurons. J Neurosci 1998, 18:7315-7327.

61. Filipovic R, Zecevic N: Interaction between microglia and oligodendrocyte cell progenitors involves Golli proteins. Ann N Y Acad Sci 2005, 1048:166-174.

62. Harauz G, Ladizhansky $\vee$, Boggs JM: Structural polymorphism and multifunctionality of myelin basic protein. Biochemistry 2009, 48:8094-8104.

63. Chernoff GF: Shiverer: an autosomal recessive mutant mouse with myelin deficiency. J Hered 1981, 72:128.

64. Lam FC, Liu R, Lu P, Shapiro AB, Renoir JM, Sharom FJ, Reiner PB: $\beta$-Amyloid efflux mediated by p-glycoprotein. J Neurochem 2001, 76:1121-1128.

65. Deane R, Wu Z, Sagare A, Davis J, Du Yan S, Hamm K, Xu F, Parisi M, LaRue B, Hu HW, Spijkers P, Guo H, Song X, Lenting PJ, Van Nostrand WE, Zlokovic $B V$ : LRP/amyloid $\beta$-peptide interaction mediates differential brain efflux of $A \beta$ isoforms. Neuron 2004, 43:333-344.

66. Miners JS, Baig S, Palmer J, Palmer LE, Kehoe PG, Love S: A $\beta$-degrading enzymes in Alzheimer's disease. Brain Pathol 2008, 18:240-252.

67. Nagara H, Suzuki K: Chronological study of oligodendroglial alterations and myelination in quaking mice. Neuropathol Appl Neurobiol 1981, 7:135-149.

68. Best TT, Skoff RP, Bartlett WP: Astroglial plasticity in hemizygous and heterozygous jimpy mice. Int J Dev Neurosci 1988, 6:39-57.

69. Dyer CA, Kendler A, Jean-Guillaume D, Awatramani R, Lee A, Mason LM, Kamholz J: GFAP-positive and myelin marker-positive glia in normal and pathologic environments. J Neurosci Res 2000, 60:412-426.

70. Maeda A, Sobel RA: Matrix metalloproteinases in the normal human central nervous system, microglial nodules, and multiple sclerosis lesions. J Neuropathol Exp Neurol 1996, 55:300-309.

71. Liuzzi GM, Latronico T, Fasano A, Carlone G, Riccio P: Interferon-beta inhibits the expression of metalloproteinases in rat glial cell cultures: implications for multiple sclerosis pathogenesis and treatment. Mult Scler 2004, 10:290-297.

72. del Zoppo GJ, Milner R, Mabuchi T, Hung S, Wang X, Berg Gl, Koziol JA: Microglial activation and matrix protease generation during focal cerebral ischemia. Stroke 2007, 38:646-651.

73. del Zoppo GJ, Frankowski H, Gu YH, Osada T, Kanazawa M, Milner R, Wang X, Hosomi N, Mabuchi T, Koziol JA: Microglial cell activation is a source of metalloproteinase generation during hemorrhagic transformation. J Cereb Blood Flow Metab 2012, 32:919-932.

74. Roher AE, Kasunic TC, Woods AS, Cotter RJ, Ball MJ, Fridman R: Proteolysis of $A$ peptide from Alzheimer disease brain by gelatinase $A$. Biochem Biophys Res Commun 1994, 205:1755-1761.

75. Backstrom JR, Lim GP, Cullen MJ, Tokes ZA: Matrix metalloproteinase-9 (MMP-9) is synthesized in neurons of the human hippocampus and is capable of degrading the amyloid- $\beta$ peptide (1-40). J Neurosci 1996, 16:7910-7919

76. Yan P, Hu X, Song H, Yin K, Bateman RJ, Cirrito JR, Xiao Q, Hsu FF, Turk JW, Xu J, Hsu CY, Holtzman DM, Lee JM: Matrix metalloproteinase-9 degrades amyloid- $\beta$ fibrils in vitro and compact plaques in situ. J Biol Chem 2006, 281:24566-24574.

77. Yin KJ, Cirrito JR, Yan P, Hu X, Xiao Q, Pan X, Bateman R, Song H, Hsu FF, Turk J, Xu J, Hsu CY, Mills JC, Holtzman DM, Lee JM: Matrix metalloproteinases expressed by astrocytes mediate extracellular amyloid- $\beta$ peptide catabolism. J Neurosci 2006, 26:10939-10948.

78. White AR, Du T, Laughton KM, Volitakis I, Sharples RA, Xilinas ME, Hoke DE, Holsinger RM, Evin G, Cherny RA, Hill AF, Barnham KJ, Li QX, Bush Al, 
Masters CL: Degradation of the Alzheimer disease amyloid $\beta$-peptide by metal-dependent up-regulation of metalloprotease activity. J Biol Chem 2006, 281:17670-17680.

79. Kotarba AE, Aucoin DS, Hoos MD, Smith SO, Van Nostrand WE: Fine mapping of the amyloid ss-protein binding site on myelin basic protein. Biochemistry 2013, 52(15):2565-2573.

doi:10.1186/1742-2094-10-134

Cite this article as: Ou-Yang and Van Nostrand: The absence of myelin basic protein promotes neuroinflammation and reduces amyloid

$\beta$-protein accumulation in Tg-5xFAD mice. Journal of Neuroinflammation 2013 10:134

\section{Submit your next manuscript to BioMed Central and take full advantage of:}

- Convenient online submission

- Thorough peer review

- No space constraints or color figure charges

- Immediate publication on acceptance

- Inclusion in PubMed, CAS, Scopus and Google Scholar

- Research which is freely available for redistribution 